\title{
Economic Literacy and Public Perception towards Government Spending on Education in Malaysia
}

\author{
Teh Kai Wen ${ }^{1}$, Siti Fatimah Ismail ${ }^{2}$, Sayed Kushairi Sayed Nordin ${ }^{3}$, \\ Nor Azriani Mohamad Nor ${ }^{4}$, Khairum Hamzah ${ }^{5}$, Nadia Hanum Amiruddin ${ }^{6}$ \\ Abdullah Al Mamun \\ ${ }^{1,2,6,7}$ Faculty of Entrepreneurship and Business, Universiti Malaysia Kelantan, Pengkalan Chepal6100 Kota \\ Bharu, Kelantan, Malaysia \\ ${ }^{3}$ Faculty of Manufacturing Engineering, Universiti Teknikal Malaysia, Hang Tuah Jaya, 76100 Durian Tunggal \\ Melaka, Malaysia \\ ${ }^{4}$ Faculty of Computer \& Mathematical Sciences, Universiti Teknologi MARA (Perlis) 02600 Arau, Perlis, \\ Malaysia \\ ${ }^{5}$ Faculty of Engineering Technology, Universiti Teknikal Malaysia, Hang Tuah Jaya 76100 Durian Tunggal \\ Melaka, Malaysia
}

\begin{abstract}
This study focuses on economic literacy and public perception towards government spending on education, especially for the 2013 Budget. The 2013 Budget demonstrates the Malaysian government's commitment to make education a national priority in the budget. From 137 respondents, the results show that economic literacy among the public was moderate, and that they had positive perception on government spending on education. Moreover, they expected the government to improve and increase its contribution on education.
\end{abstract}

Keywords: economic literacy, government spending, public perception

\section{INTRODUCTION}

The global financial crisis began in July 2007. The crisis causes the world economy to continue to struggle even after four years has passed. Developing countries are still the main drivers contributing towards global growth, but the speed of the output has reduced. If developing countries plan to regain pre-crisis growth rates, they must emphasize on internal productivity-enhancing policies. For high-income countries, they will continue to focus on restructuring and fiscal consolidation [1]. As the world economy continues to struggle until today, a country's budget is important to ensure better quality of life for the citizens.

The budget of a government is a legal document that summarizes or forecasts the expenditures and revenues of the government for a specific period of time. The main purpose of a government's budget is to ensure that a sufficient amount of money is allocated for necessary or important expenditures. A government's budget may slowly promote or improve economic growth in certain areas of the economy. Better economy means better quality of life for the citizens.

The 2013 Budget demonstrates the Malaysian government's continual commitment to make education a national priority by allocating RM38.7 billion for the Ministry of Education (MoE) for operational and developmental expenses. The measures introduced in the budget are in line with the initiatives outlined in the preliminary report on Malaysia Education Blueprint 2013-2025 launched by MoE on September $11^{\text {th }}$, which aims to transform the national education system into a high-performing system.

Determining the factors affecting public opinion on government spending is an important part of a larger cycle. If the budget deficit, for example, is a driving factor for public opinion on spending, then citizens may choose to vote for a politician who promises to reduce the deficit [2].

If public opinion on government spending can be such a powerful predictor for actual spending and budgetary policies, what is then the predictor of public opinion on government spending? Only a few papers examined the public perception on spending. This paper focuses on public perception and the roles of the media on government spending on education in the 2013 Budget. Besides that, the aim of this study is also to measure the level of economic literacy among Malaysians.

The 2013 Budget plays a vital role in improving the quality life of the citizens, spending prudently and reducing the fiscal deficit, with an overall objective of prioritizing the well-being of the citizens. The 2013 Budget mainly benefits women, students/youths, pensioners/senior citizens, low-income civil servants, SMEs/entrepreneurs and residents of East Malaysia.

The problem addressed in this research was that in a society, there are different opinions regarding government spending from different groups of people. Not everybody thinks alike. 
As a society, there are people that do not agree with the budget allocation set by the government. They feel that it only benefits some people, as mentioned above, and disregards others. Besides that, citizens do not understand why the government allocates most money to those people. Is the misunderstanding caused by the factors mentioned above? Although there were many who cared or paid attention to the 2013 Budget speech delivered by our Prime Minister, but did they really understand why the government allocated part of the money for education?

\subsection{Budget 2013}

\section{LITERATURE REVIEW}

The 2013 Budget was announced by the Prime Minister of Malaysia on $28^{\text {th }}$ September 2012. In [3], the 2013 Budget focused on improving the quality of life of the residents, ensuring sustainable economic growth, spending prudently and reducing the fiscal deficit, with an overall objective of prioritizing the well-being of the citizens. The government will assure that citizens will receive excellent services and maximum benefit by implementing the development of projects and programs stated in the 2013 Budget. Therefore, the theme for the 2013 Budget is "Prospering the Nation, Enhancing Well-being of the Citizen: A Promised Fulfilled".

The total budget allocation for 2013 is RM251.6 billion, which is used to develop projects and programs focusing on the well-being of the residents and national development. Of the total amount, RM201.9 billion or $80 \%$ is allocated for operating expenditure and RM49.7 billion or $20 \%$ is allocated for Development Expenditure. Operating expenditure includes emoluments of RM58.6 billion (23.3\%), supplies and services of RM33.7 billion (13.4\%), fixed charge and grants of RM107.3 billion (42.6\%), purchase of assets of RM1.1 billion $(0.4 \%)$ and other expenditures of RM1.2 billion $(0.5 \%)$.

In the 2013 Budget, the government has allocated $21 \%$ from the total budget for education and training. A sum of RM38.7 billion is allocated for the MoE for operational and developmental expenditures. The government made such decision because they are aware that education and training are pre-requisites for the prosperity of the country and the well-being of the citizens [3].

\subsection{Public Perception}

Research on public opinion on spending has mostly taken the form of investigating how public opinion affects policy. While this paper focuses on budgeting and public opinion on spending, it is important to note that public opinion also tends to influence the overall policy direction. In [4], it is found that shifts in public opinion tend to lead to congruent shifts in public policy in the United States, and in cases where there was a change in policy, that policy change followed a similar change in public opinion in $66 \%$ of the cases studied by the authors.

Public perception refers to the understanding of the people towards a statement, public or official issue. It is very difficult to overcome negative public perception. While, government spending can refer to expenses made by local, regional and national governments [5]. A government may spend on few areas including future investments, acquisitions, and transfer payments for the well-being of the citizens and national development.

\subsection{Economic Literacy}

Education is an important factor influencing the economic literacy of a person. According to [6], a person with a higher level of education will most likely understand the factors affecting national economy because they are well-informed and capable of understanding complex economic events.

With the increasing challenge of sustaining economic growth within the continent, the search for the foundations of growth and sustainability in Malaysia is increasing, and the importance of literacy is becoming recognized. This phenomenon is currently observed in most developing countries, including Africa, and it is a crucial element of emerging literacy-based economies. Better education increases the stock of human capital in the economy, improves the efficiency of the workforce and raises aggregate productivity.

It was an assessment on the economic literacy of the U.S. public [6]. The collected survey data were used to measure economic literacy of the public, to identify factors affecting economic literacy, and to evaluate the influence of economic literacy on public opinion about current economic issues. A telephone interview was conducted to gather information from a random sample of 1,005 people whose age were 18 years or older. The result suggested that economic literacy had a direct effect on public opinion. The economic literacy was significant with variables, which include Federal Reserve should set monetary policy, reduce federal budget deficit by increasing taxes on business, encourage economic growth by increasing government spending to provide jobs, the U.S. government should prohibit increase in oil and gas prices if oil supply is reduced due to crises in the Middle East and limit imports from other countries to reduce trade deficit. 


\section{METHODOLOGY}

137 respondents were given a set of questionnaire. The questionnaire consists of 3 parts; Part A is demographic, Part B is questions on economic literacy and Part C is public perception on government spending. Part B is true/false questions (see appendix) and questions in Part $\mathrm{C}$ are measured in 7 range of Likert scale format (see Table 4). Descriptive statistics will be performed for the analysis.

IV. FINDINGS

Table 1 Background of Respondents

\begin{tabular}{lrcc}
\hline & & Frequency & \% \\
\hline Age & & & \\
& 20 and below & 2 & 1.5 \\
& $21-30$ & 128 & 93.3 \\
& $31-40$ & 2 & 1.5 \\
& $41-50$ & 2 & 1.5 \\
\hline Total & 50 and above & 3 & 2.2 \\
\hline Gender & & 137 & 100 \\
& & & \\
& Male & 99 & 72.3 \\
\hline Total & Female & 38 & 27.7 \\
\hline Occupation & & 137 & 100 \\
& Student & 137 & 100 \\
& Private Sector & 22 & 78.1 \\
& Government Servant & 4 & 16.1 \\
& Entrepreneur & 1 & 2.9 \\
& Others & 3 & 0.7 \\
\hline Total & & 137 & 2.2 \\
\hline
\end{tabular}

Income Level (RM)

\begin{tabular}{lrcc} 
& 1500 and below & 105 & 76.6 \\
& $1501-3000$ & 18 & 13.1 \\
& $3001-4500$ & 12 & 8.8 \\
& $4501-6000$ & 2 & 1.4 \\
\hline Total & & 137 & 2.2 \\
\hline Race & Malay & 54 & \\
& Chinese & 69 & 39.4 \\
& Indian & 14 & 50.4 \\
\hline Total & & 137 & 10.2 \\
\hline
\end{tabular}

According to Table 1, the largest group of respondents in this study aged between 21-30 years old (93.3\%). Majority of the respondents were female $(72.3 \%)$, while male represented $27.7 \%$. With regard to occupations, most respondents were students $(78.1 \%) .16 .1 \%$ of respondents worked in the private sector, and $2.9 \%$ were government servants. The highest percentage of respondents earned below RM 1500 (76.6\%), followed by RM 1501-RM $3000(13.1 \%)$ income earners. Chinese represented about half of the respondents $(50.4 \%)$, followed by Malay (39.4\%) and Indian (10.2\%).

Table 2 Economic Literacy among Respondents

\begin{tabular}{ccc}
\hline Score $(\boldsymbol{\%})$ & Frequency & \% \\
\hline 35 & 2 & 1.5 \\
40 & 3 & 2.2 \\
45 & 6 & 4.4 \\
50 & 6 & 4.4 \\
55 & 13 & 9.5
\end{tabular}




\begin{tabular}{ccc}
60 & 13 & 9.5 \\
65 & 18 & 13.1 \\
70 & 20 & 14.6 \\
75 & 26 & 19.0 \\
80 & 12 & 8.8 \\
85 & 10 & 7.3 \\
90 & 6 & 4.4 \\
95 & 2 & 1.5 \\
\hline Total & 137 & 100.0 \\
\hline
\end{tabular}

Table 3 Economic Literacy Grading

\begin{tabular}{ccc}
\hline Score & Indicator & $\%$ \\
\hline $0-49$ & Weak & 8 \\
$50-79$ & Moderate & 70 \\
$80-100$ & Good & 22 \\
\hline
\end{tabular}

Table 2 shows the respondents' scores (correct answers) on their literacy about economy. The highest score is $95 \%$, while the lowest is $35 \%$. 30 of them (22\%) scored above $80 \%$. The mode of the score is $75 \%$. Meanwhile, referring to Table 3, the scores were then categorized into three indicators, namely weak, moderate and good. Majority respondents (70\%) scored in the range of $50-79$, which is moderate. $22 \%$ obtained good scores between $80-100$, and $8 \%$ scored between $0-49$, which is weak.

Table 4 Perception towards Government Spending

Perception towards Government Spending in Education

Mean

\begin{tabular}{l} 
1. I am very pleased with the Budget allocation for education in the year 2013. \\
2. Provision issued by the government to increase the savings in National Education \\
Savings Scheme (SSPN) is relevant. \\
3. Provision issued by the government of pilot project for TASKA OKU (disabled \\
children, namely down syndrome, autism, blind or partially sighted, hearing and \\
speaking disabilities) is relevant. \\
4. 1 Malaysia Training Scheme, also known as SL1M introduced by the government is \\
relevant. \\
5. Provision issued by the government towards the increasing value of the 1Malaysia \\
Book Voucher programme is relevant. \\
6. Provision issued by the government to provide Schooling Assistance of RM100 to all \\
primary and secondary students is relevant. \\
7. Provision issued by the government to provide Food Supplement Programe (RMT) to \\
primary and secondary students is relevant. \\
$\begin{array}{l}\text { 8. Provision issued by the government to provide assistance of RM 10,000 cash rebate } \\
\text { and a } 2 \% \text { interest rate subsidy to replace buses exceeded } 25 \text { years is relevant. } \\
\text { 9. Provision issued by the government to allocate RM } 1.2 \text { billion for pre-school } \\
\text { education (MOE, PERMATA and etc.) is relevant. } \\
\text { 10. Provision issued by the government to provide a } 10 \% \text { discount for consistent } \\
\text { repayment of PTPTN loan is relevant. }\end{array}$ \\
\hline Overall Mean
\end{tabular}

Based on the Table 4, most respondents had positive perception towards government spending on education. As seen in the table, most mean scores for public perception [on various aspects] are above 4, which means that they agreed with the decision made by the government. Only one mean score was slightly lower than 4.

\section{CONCLUSION}

In conclusion, it can be said that economic literacy among the public was at a moderate level with the majority scoring in the range of 50-79, even though most respondents were bachelor's degree holders who are usually less aware of current economic issues. Public perception on government spending on education was also indicated as moderate, with an overall mean score of 4.61 out of 7. This shows that Malaysians expect the ruling government to improve and contribute more of its expenditure on education. 


\section{REFERENCES}

[1] A. Burns, Global Economic Prospects: Assuring growth over the medium term, World Bank Annual Report, 2013

[2] Downey, K. M, What factors impact public opinion on federal government spending?, Master diss., Georgetown University, Washington, DC, 2009

[3] Ministry of Finance Malaysia. (2012, September 28). Retrieved on April 12, 2013, from http://www.treasury.gov.my/index.php?option=com_content\&view=article\&id=2280\%3Abajet-2012\&catid=87\%3Acatbajettahunan\&Itemid $=195 \&$ lang $=$ my

[4] I.P. Benjamin and R. Y. Shapiro, Effect of Public Policy on Economy, The American Political Review, 77(1), 1983, 175-190.

[5] Ellis, J, (2013). wiseGEEK. Retrieved on February 12, 2013, from http://www.wisegeek.com/what-is-government-spending.htm

[6] Walstad, W. B, 1994. Economic Knowledge and Public Opinion on Economic Issues. Paper presented at the Annual Meeting of the Midwest Economics Association Chicago, IL, 1994, 33

\begin{tabular}{|c|c|c|c|}
\hline \multicolumn{4}{|c|}{ APPENDIX } \\
\hline No & Questions & True & False \\
\hline 1 & $\begin{array}{l}\text { Economics is the study of the production, distribution and consumption of wealth in human } \\
\text { society. }\end{array}$ & & \\
\hline 3 & Foreign Direct Investment is one of the indicators to measure economic growth. & & \\
\hline 4 & $\begin{array}{l}\text { Prices of RON95 and Diesel have been increased by } 20 \text { sen per litre, effective } 3 \text { September } \\
2013 .\end{array}$ & & \\
\hline 6 & Malaysia currently levies two forms of consumption tax - sales tax and service tax. & & \\
\hline 7 & $\begin{array}{l}\text { The Malaysian government subsidizes and control prices on a lot of essential items such as } \\
\text { palm oil, cooking oil, petrol, flour, bread, rice and other essentials. }\end{array}$ & & \\
\hline 8 & $\begin{array}{l}\text { Canada, Australia, India and Singapore are the countries which have implemented Goods and } \\
\text { Services Tax. }\end{array}$ & & \\
\hline 9 & $\begin{array}{l}\text { Inflation is a decrease in the price of a basket of goods and services that is representative of the } \\
\text { economy as a whole. }\end{array}$ & & \\
\hline 13. & $\begin{array}{l}\text { Do you know that we can have inflation and deflation by changing the amount of money in the } \\
\text { system? }\end{array}$ & & \\
\hline 14. & $\begin{array}{l}\text { Do you know that the nation's nominal Gross Domestic Product is expected to exceed RM1 } \\
\text { trillion? }\end{array}$ & & \\
\hline 15. & Do you know what Fiscal-Policy is? & & \\
\hline 16. & Do you know what the Monetary - Policy is? & & \\
\hline 17. & Do you know inflation is too many dollars chasing too few goods? & & \\
\hline 18. & $\begin{array}{l}\text { Do you know that one of the most important uses of taxes is to finance public goods and } \\
\text { servics? }\end{array}$ & & \\
\hline 19. & Do you know that money isn't just pieces of paper? & & \\
\hline
\end{tabular}

